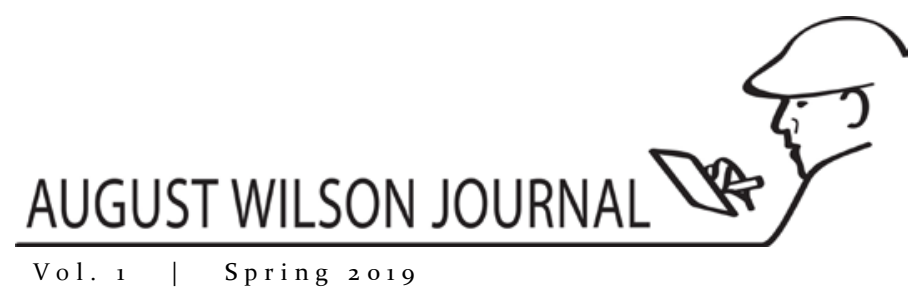

\title{
A Stage Review of Radio Golf: New African Grove Completes the Cycle
}

\author{
New African Grove Theatre Company \\ South Fulton Arts Center; College Park, Georgia \\ July 13-22, 2018 \\ Directed by Natasha Young \\ By Christopher Bell \\ Associate Professor of English, University of North Georgia
}

... it can be difficult to train performers in the demanding

rigors of Wilson's language.

- Keith Franklin, Artistic Director

\begin{abstract}
A stage review of August Wilson's Radio Golf at the New African Grove Theatre Company in College Park, Georgia, July 2018.

Keywords

August Wilson, Radio Golf, New African Grove Theatre, Pittsburgh, American Century Cycle, William Shakespeare, David Mamet, Natasha Young, Keith Franklin, Nic Starr
\end{abstract}

August Wilson most certainly would have appreciated the performance of Radio Golf by the New African Grove Theatre Company on July 21, 2018, which took place at the South Fulton Arts Center in College Park, Georgia, which is a former public school. The location is fitting, as it reflects Wilson's own nascent work with Black Horizons, a community theater he helped found in the late 1960 s that was dedicated to raising the consciousness of the black populace and whose performance space was the A. Leo Weil Elementary School on Centre Avenue. New African Grove is also a small community theater committed, according to the company's Artistic Director Keith Franklin, to staging plays centered on the African diaspora. And while Wilson's work has reached the heights of Broadway and London's West End, his work centers on characters struggling day to day to have their voices heard and dignity recognized, much like the tireless efforts of this small

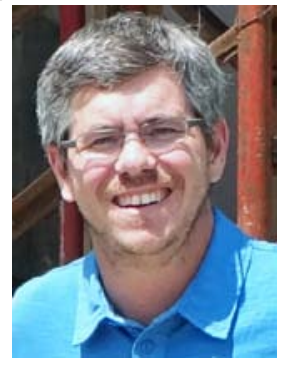

Chris Bell outfit that stages shows for a peak audience of eighty. What Wilson would have found most delightful about this New African Grove performance is that it marked the company's completion of the entire American Century Cycle, one of the few theaters in the country to accomplish this feat.

I asked Franklin what the most difficult part of completing the cycle was. He said that because the company draws many actors from the community it can be difficult to train 
performers in the demanding rigors of Wilson's language. These performers are in some ways more obligated to that aspect of the playwright's work, as the set and costuming are constrained by a limited budget, not to mention the South Fulton Arts Center stage is tiny. The director for this production, Natasha Young, also points out with a chuckle that the actors' compensation is meager, not even "What would allow anyone to go on a shopping spree." These actors and the crew are truly dedicated to bringing August Wilson's voice to the community and that dedication was evident in the production.

It's the connection to the characters, a community of people forgotten by the city of Pittsburgh and largely unknown to the world outside the city, that New African Grove captured in its performance of Radio Golf. When asked what was most satisfying about completing the American Century Cycle, Young said it was "the joy of knowing that we have provided a service to the community" That service is honoring the legacy of August Wilson, himself a fifteen-year-old high school dropout who eventually left the troubled streets of his youth to become one of America's great playwrights, but took the mostly ignored members of the Hill District community with him and put them on stage.

As noted, the New African Grove performers showed great care for Wilson's work. Nic Starr in particular stood out as Sterling, playing the role with an abundance of humor. When needed, however, the actor, a physically imposing man, convinces the audience that Sterling is a threat to Harmond and Roosevelt, two businessmen whose current venture includes a plan to tear down a house they purchased illegally from its rightful owner, Old Joe Barlow. When Sterling learns of this plan, Starr turns off the charm and becomes threatening, bearing down on the other characters: "If you fuck with Mr. Barlow's house ... if you move one goddam pebble . . you gonna have to answer to me on the battlefield." As the lights come down on the first act with these lines, the audience audibly exhaled, clearly moved by Starr's sudden turn in demeanor.

Sterling's main target becomes Roosevelt, and Paris Crayton plays the latter character how Wilson draws him, as an overly ambitious businessman who only cares about how much money he can stack in a metaphorical wheelbarrow. Roosevelt has some of the most unseemly lines in Wilson's drama, such as his dressing down of Sterling, after the latter accuses of Roosevelt of holding back the black community by not giving back to it, despite his obvious means to do so: “It's not my fault your daddy's in jail, your mama's on drugs, your little sister's pregnant and the kids don't have any food 'cause the welfare cut off the money . .. Get up off your ass . . . quit stealing ... get a job ... pay your taxes." While none of these things are true for Sterling and are horrific sweeping generalizations of the black community itself, Crayton delivered them as needed, with the conviction of the character himself, one who glances at a person once and believes he can tell the individual's entire history.

In the middle of the fray stands Franklin, the aforementioned artistic director of New Grove, who plays Harmond, the play's protagonist. An ambitious man, Harmond seeks to revitalize the run-down Hill District with his business plan, while simultaneously running for mayor. Ultimately, Harmond decides neither the commercial venture or mayoral candidacy is worth more than Old Joe being allowed to keep his house. Although Franklin plays Harmond as initially bewildered as he loses control of his business and political aspirations, he later turns decidedly defiant. When Roosevelt tells Harmond he plans to purchase the controlling stake in Bedford Hills and will use a white man's financial backing as a silent partner, Harmond calls Roosevelt, a lifelong friend, "The shuffling, grinning nigger in the woodpile." Franklin perfectly captures the character's disgust. The actor also convincingly shows that Harmond is a changed man at the end of the play, one who relishes the opportunity to stand with a group of local activists, led by Sterling, protesting the imminent destruction of Old Joe's House.

New African Grove's performance of Radio Golf was splendid. More importantly, that the production served as the company's completion of August Wilson's American Century Cycle seems fitting. The play stresses that black leaders are needed to fight for the 
community, not strip it of its vitality, as Roosevelt attempts to do. The work is Wilson's most overtly political drama, and, as the last play he composed before his death in 2005, it serves as a reminder that the playwright's first experiences were with a community theater that sought to raise the consciousness of the black community. The dramatist would have been pleased to know of a similar troupe so dedicated to presenting his work to that same community, which, despite its financial limitations, has managed to complete all ten of his magnificent plays in fine fashion.

And what's in store next for New African Grove? It plans to start a second run of the American Century Cycle, beginning with Gem of the Ocean in July of 2019.

\section{Works Cited}

Wilson, August. Radio Golf. Theatre Communications Group. 2007.

\section{Author Bio}

Dr. Christopher Bell is Associate Professor of English at the University of North Georgia where he teaches courses in American Literature, African American Literature, and World Drama.

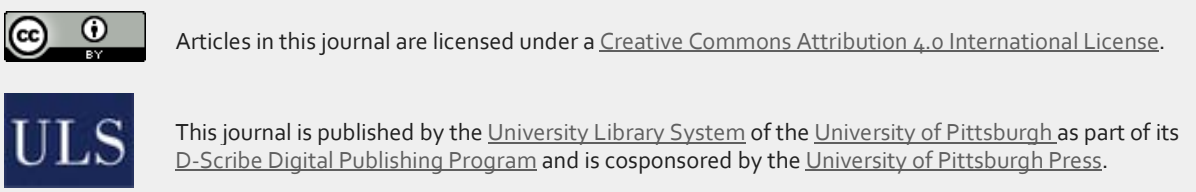

